\author{
The anti-science strain pervading the right wing in the United States is the last thing the country \\ needs in a time of economic challenge.
}

$1 / 7$ he four corners of deceit: government, academia, science and media. Those institutions are now corrupt and exist by virtue of deceit. That's how they promulgate themselves; it is how they prosper." It is tempting to laugh off this and other rhetoric broadcast by Rush Limbaugh, a conservative US radio host, but Limbaugh and similar voices are no laughing matter.

There is a growing anti-science streak on the American right that could have tangible societal and political impacts on many fronts - including regulation of environmental and other issues and stemcell research. Take the surprise ousting last week of Lisa Murkowski, the incumbent Republican senator for Alaska, by political unknown Joe Miller in the Republican primary for the 2 November midterm congressional elections. Miller, who is backed by the conservative 'Tea Party movement', called his opponent's acknowledgement of the reality of global warming "exhibit 'A' for why she needs to go".

The right-wing populism that is flourishing in the current climate of economic insecurity echoes many traditional conservative themes, such as opposition to taxes, regulation and immigration. But the Tea Party and its cheerleaders, who include Limbaugh, Fox News television host Glenn Beck and Sarah Palin (who famously decried fruitfly research as a waste of public money), are also tapping an age-old US political impulse - a suspicion of elites and expertise.

Denialism over global warming has become a scientific cause célèbre within the movement. Limbaugh, for instance, who has told his listeners that "science has become a home for displaced socialists and communists", has called climate-change science "the biggest scam in the history of the world". The Tea Party's leanings encompass religious opposition to Darwinian evolution and to stem-cell and embryo research - which Beck has equated with eugenics. The movement is also averse to science-based regulation, which it sees as an excuse for intrusive government. Under the administration of George W. Bush, science in policy had already taken knocks from both neglect and ideology. Yet President Barack Obama's promise to "restore science to its rightful place" seems to have linked science to liberal politics, making it even more of a target of the right.

US citizens face economic problems that are all too real, and the country's future crucially depends on education, science and technology as it faces
"The country's future crucially depends on education, science and technology." increasing competition from China and other emerging science powers. Last month's recall of hundreds of millions of US eggs because of the risk of salmonella poisoning, and the Deepwater Horizon oil spill, are timely reminders of why the US government needs to serve the people better by developing and enforcing improved sciencebased regulations. Yet the public often buys into anti-science, antiregulation agendas that are orchestrated by business interests and their sponsored think tanks and front groups.

In the current poisoned political atmosphere, the defenders of science have few easy remedies. Reassuringly, polls continue to show that the overwhelming majority of the US public sees science as a force for good, and the anti-science rumblings may be ephemeral. As educators, scientists should redouble their efforts to promote rationalism, scholarship and critical thought among the young, and engage with both the media and politicians to help illuminate the pressing science-based issues of our time.

\section{A destabilizing force}

\section{Public allegations threaten the impartiality of misconduct inquiries.}

nvestigations into charges of scientific misconduct are unpleasant for all concerned. Emotions run high and careers are jeopardized. As a consequence, it is crucial that all those involved, both directly and indirectly, behave with dignity and restraint.

But events around such an investigation in Germany have taken a troubling and damaging turn from such good practice in the past few months. An unknown agitator using the presumed pseudonym Marco Berns is engaged in an e-mail and Internet offensive against two biomedical researchers whom he accuses of scientific fraud.

Berns's libellous messages are targeted at dermatologist Ralf Paus and immunologist Silvia Bulfone-Paus, a married couple who both hold joint positions at the University of Manchester, UK, and the
University of Lübeck, Germany.

The trial-by-Internet is disturbing a formal investigation, organized by the Research Center Borstel in Germany and begun in July, into some of the pair's publications.

Berns began sending e-mails to those involved in the inquiry shortly after it started, and has since widened his reach to researchers, politicians and journalists. He provides links to an untraceable website hosted in Panama, which contains more material.

Those involved in the investigation are rightly appalled by the destabilization that these public accusations could cause. Claims of scientific misconduct must be assessed in confidence to protect both accused and whistle-blower from rumours that could prejudice the inquiry.

But under the shadow of anonymity, it seems that little can be done to stop Berns. Upset and uncertainty will remain until the investigation is complete. Everyone involved must be presumed innocent until then, and the inquiry should report as quickly as possible without sacrificing fairness, impartiality and normal procedure. That is the best that can be done in this unfortunate affair. 